\title{
New fossil hangingflies (Mecoptera, Raptipeda, Bittacidae) from the Middle Jurassic to Early Cretaceous of Northeastern China
}

\author{
Xiaoguang YANG \\ Dong REN \\ Chungkun SHIH \\ College of Life Sciences, Capital Normal University, 100048 Beijing (China) \\ yangxiaoguang86@163.com \\ rendong@mail.cnu.edu.cn \\ chungkun.shih@gmail.com
}

Yang X.-G., Ren D. \& Shih C.-K. 2012. - New fossil hangingflies (Mecoptera, Raptipeda, Bittacidae) from the Middle Jurassic to Early Cretaceous of Northeastern China. Geodiversitas 34 (4): 785-799. http://dx.doi.org/10.5252/g2012n4a4

KEY WORDS

Mecoptera, Bittacidae, Insect fossil, Jiulongshan Formation, Yixian Formation, new species, new genus.

\begin{abstract}
A new genus with a new species, Exilibittacus lii n. gen., n. sp., and a new species, Megabittacus spatiosus n. sp., are described and illustrated. Both of them belong to the family Bittacidae (Mecoptera). These specimens were collected respectively from the Middle Jurassic of Jiulongshan Formation at Daohugou in Inner Mongolia and from the Late Jurassic to Early Cretaceous of Yixian Formation at Dawangzhangzi in Liaoning, China. In Exilibittacus n. gen., both RP+MA and MP have four branches in forewings, while both have three branches in hind wings, and RP1+2 and MP3 are not forked. This is the first time that the character 'MP with three branches in hind wings' is reported for the Bittacidae. Based on data on Megabittacus spatiosus n. sp., the diagnosis of Megabittacus is revised and a key to the known species is provided. Morphological changes in hangingflies from Middle Jurassic to present are discussed based on body length, wing length, and forewing/body length ratio.
\end{abstract}




\section{MOTS CLÉS \\ Mecoptera, \\ Bittacidae, \\ insectes fossiles, \\ Formation Jiulongshan, \\ Formation Yixian.}

\begin{abstract}
RÉSUMÉ
De nouveaux fossiles de "mouches-scorpion» (Mecoptera, Raptipeda, Bittacidae) du Jurassique Moyen au Crétacé inférieur du nord-est de la Chine.

Exilibittacus lii n. gen., n. sp. et Megabittacus spatiosus n. sp. sont décrits et appartiennent à la famille des Bittacidae (Mecoptera). Les spécimens proviennent, respectivement, du Jurassique moyen de la Formation Jiulongshan (Daohugou, Mongolie intérieure) et du Jurassique supérieur au Crétacé inférieur de la Formation Yixian (Dawangzhangzi, Liaoning, Chine). Chez Exilibittacus n. gen., RP+MA et MP ont chacune quatre branches aux ailes antérieures, tandis que ces nervures ont trois branches aux ailes postérieures, et RP1+2 et MP3 ne sont pas branchées. C'est la première fois que le caractère "MP avec trois branches aux ailes postérieures" est observé chez les Bittacidae. Basée sur des données sur Megabittacus spatiosus n. sp., la diagnose de Megabittacus est révisée et une clé des espèces connues est fournie. Les changements morphologiques chez les "mouches-scorpion" du Jurassique Moyen à l'actuel sont discutés sur la base de la longueur du corps, la longueur des ailes, et du rapport de longueur ailes antérieures/corps.
\end{abstract}

\section{INTRODUCTION}

Bittacidae, a large family of Mecoptera which is one of the less diverse insect Orders, is considered to be a sister group of Cimbrophlebiidae. Together, Bittacidae and Cimbrophlebiidae form the infraorder of Raptipeda (Willmann 1977, 1989). Bittacids and cimbrophlebiids share the same special tarsi structure: the fifth tarsomere can be folded against the fourth and tarsus has only one claw. Their wing venations are similar, but cimbrophlebiids can be easily identified by long and branched $2 \mathrm{~A}$, which is short and unbranched in bittacids (Willmann 1977, 1989). Usually bittacids wings are slender and both $\mathrm{RP}+\mathrm{MA}$ and MP veins have four branches, except for Orobittacus RP+MA with three branches. They are called hangingflies because they commonly hang their bodies by two fore legs from branches among low vegetation, while using free middle and hind legs to catch insects (Petrulevičius et al. 2007). At present, there are 16 extant genera including about 270 species of Bittacidae (Krzemiński 2007). Extant bittacids are distributed globally in both temperate and warm tropical climates. In addition to extant bittacids, about 29 fossil genera have been described (Tillyard 1933; Handlirsch 1939; Martynov 1951; Byers 1979; Villegas \& Byers 1981; Ren 1993, 1997;
Novokshonov 1997; Petrulevičius \& Jarzembowski 2004; Petrulevičius et al. 2007). Fossil records show a broadest generic diversity occurring in the Jurassic (Novokshonov 2002).

To date, eight fossil genera of hangingflies from the Middle Jurassic to the Early Cretaceous have been recorded in China: Liaobittacus Ren, 1993 from the Haifanggou Formation; Jichoristella Ren, 1994 from the Lushanfeng Formation; Megabittacus Ren, 1997, and Sibirobittacus Sukatsheva, 1990 from the Yixian Formation; Mongolbittacus Petrulevičius, Huang \& Ren, 2007, Formosibittacus Li, Ren \& Shih, 2008, Jurahylobittacus Li, Ren \& Shih, 2008, and Decoribittacus Li \& Ren, 2009 from the Jiulongshan Formation.

A new hangingfly, Exilibittacus lii n. gen., n. sp., is described in this paper. The specimen was collected from the Jiulongshan Formation at Daohugou Village of Ningcheng County in Inner Mongolia, China. The age of the Daohugou fossil-bearing beds is considered to be the Middle Jurassic (Ren et al. 1995; Ren \& Krzemiński 2002; Ren et al. 2002; Shen et al. 2003; Chen et al. 2004; Liu et al. 2004; Gao \& Ren 2006; Huang et al. 2006; Ji et al. 2006). A new species, Megabittacus spatiosus n. sp., was collected from the Yixian Formation at Dawangzhangzi in Lingyuan, western Liaoning, China. The 
age of the Yixian Formation remains debatable. Three different opinions about the age: the Late Jurassic (Ren 1997; Zheng et al. 2003), transition from the Late Jurassic to Early Cretaceous (Chen et al. 2004; Wang et al. 2004, 2005), and the Early Cretaceous (Swisher et al. 1999; Li et al. 2001; Pang et al. 2002; Zhou et al. 2003), have been proposed based on both biostratigraphic and radiometric geochronologies. By comparing the Yixian biota with the Solnhofen biota of Germany, the Purbeck biota in England and the Late Jurassic Terori-type and Ryoseki-type floras in Japan, Wang et al. (2005) considered the synthetic age of the Yixian Formation as the Late Jurassic-Early Cretaceous (the Late Tithonian to the Berriasian).

\section{MATERIAL AND METHODS}

The fossil specimens were examinated by a LEICA MZ12.5 dissecting microscope and illustrated with the aid of a camera lucida attached to the microscope. All specimens are deposited in the Key Laboratory of Insect Evolution \& Environmental Changes, the College of Life Sciences, Capital Normal University, Beijing, China (CNU, Ren Dong, Curator). Photographs of whole specimens were taken by Nikon D100 digital camera coupled to a Nikkor $105 \mathrm{~mm}$ macro lens, and detailed photographs were made by using Nikon SMZ1000 stereomicroscope. The terminology for wing venation follows Kukalová-Peck (1983, 1991), "Kreuz der Bittaciden" is defined as the cross-veins of [RP3+4+MA-MP1+2, MP1+2-MP3] (Novokshonov 1993). The venational nomenclature of Kukalová-Peck is compared with that of Byers (1979) in Table 1 for easy reference.

$\begin{array}{ll}\text { ABBREVIATIONS } \\ \text { Venation } & \text { nomenclature } \\ \text { RA } & \text { anterior radius; } \\ \text { RP } & \text { posterior radius; } \\ \text { MA } & \text { anterior media; } \\ \text { MP } & \text { posterior media; } \\ \text { CuA } & \text { anterior cubitus; } \\ \text { AA } & \text { anterior anal; } \\ \text { AP } & \text { posterior anal; } \\ \text { ScP } & \text { posterior subcosta. }\end{array}$

TABLE 1. - Comparison of venation nomenclatures between Kukalová-Peck and Byers.

\begin{tabular}{cc}
\hline $\begin{array}{c}\text { Kukalová-Peck system } \\
(\mathbf{1 9 8 3 , 1 9 9 1 )}\end{array}$ & Byers system (1979) \\
\hline ScP & Sc \\
RA & R1 \\
RP & RS \\
MA & R5 \\
MP & $\mathrm{M}$ \\
MP4 + CuAl +2 & $\mathrm{M} 4$ \\
CuA3 +4 & $\mathrm{CuA}$ \\
$\mathrm{CuP}$ & $\mathrm{CuP}$ \\
$\mathrm{AA3}+4$ & $\mathrm{~A}$ \\
$\mathrm{AP} 1+2$ & $2 \mathrm{~A}$ \\
AP3 +4 & $3 \mathrm{~A}$ \\
\hline
\end{tabular}

\section{SYSTEMATICS}

Order MECOPTERA Packard, 1886

Infraorder RAPTIPEDA Willmann, 1977

Family BITTACIDAE Handlirsch, 1906

Genus Exilibittacus n. gen.

TyPe SPECIES. - Exilibittacus lii n. sp.

ETYMOLOGy. - The generic name is derived from the Latin word "exil-" (weak) and bittacus (a recent genus of Bittacidae). Gender masculine.

Diagnosis. - One crossvein between ScP and RA; RA sharply bent distally; RP+MA forking before the fork of MP; "Kreuz der Bittaciden" aligned, MP3+MP4+CuA1+2 forking before posterior part of "Kreuz der Bittaciden" (if existing); one crossvein between MP4+CuA1+2 and $\mathrm{CuA3}+4 ; \mathrm{AA} 3+4$ short; Forewing both $\mathrm{RP}+\mathrm{MA}$ and $\mathrm{MP}$ with four branches, but hind wing, three branches.

\section{REMARKS}

Exilibittacus n. gen. can be assigned to the infraorder Raptipeda (Willmann 1977, 1989) on the characteristics of legs: long and slender, with a single, predatory claw, the fifth tarsomere folding back toward fourth. Furthermore, it can be classified into the Bittacidae by $\mathrm{AA} 3+4$ short and $\mathrm{AP} 1+2$ absent on a well-preserved forewing, in contrast to cimbrophlebiids with AA3+4 long and AP1+2 very long and branched.

Forewing of Exilibittacus n. gen. is similar to Antiquanabittacus Petrulevičius \& Jarzembowski, 2004 and Mongolbittacus Petrulevičius, Huang \& 
TABLE 2. - A list of fossil and extant bittacid species examined. Abbreviation: fm., formation; LR, Length ratio of forewing/body.

\begin{tabular}{|c|c|c|c|c|c|c|}
\hline Species & Distribution & Age & Sex & Body (mm) & Forewing (mm) & LR \\
\hline Liaobittacus longanteenatus Ren, 1993 & \multicolumn{2}{|c|}{ Haifanggou Fm. J2 } & Male & 20 & 21 & 1.05 \\
\hline $\begin{array}{l}\text { Mongolbittacus daohugouensis } \\
\text { Petrulevičius, Huang \& Ren, } 2007\end{array}$ & $\begin{array}{l}\text { Jiulongshan } \\
\text { Fm. }\end{array}$ & J2 & $?$ & 9.5 & 12.5 & 1.32 \\
\hline $\begin{array}{l}\text { Formosibittacus macularis } \\
\quad \mathrm{Li}, \text { Ren \& Shih, } 2008\end{array}$ & $\begin{array}{l}\text { Jiulongshan } \\
\text { Fm. }\end{array}$ & $\mathrm{J} 2$ & Female & 21 & 23 & 1.10 \\
\hline $\begin{array}{l}\text { Jurahylobittacus astictus } \\
\text { Li, Ren \& Shih, } 2008\end{array}$ & $\begin{array}{l}\text { Jiulongshan } \\
\text { Fm. }\end{array}$ & $\mathrm{J} 2$ & Male & 18 & 12 & 0.67 \\
\hline Exilibittacus lii n. gen., n. sp. & $\begin{array}{l}\text { Jiulongshan } \\
\text { Fm. }\end{array}$ & $\mathrm{J} 2$ & Female & 12 & 7.5 & 0.63 \\
\hline Megabittacus colosseus Ren, 1997 & Yixian Fm. & J3-K1 & $?$ & 40 & 40 & 1.00 \\
\hline Sibirobittacus atalus Ren, 1997 & Yixian Fm. & $\mathrm{J} 3-\mathrm{K} 1$ & $?$ & 18 & 18.5 & 1.03 \\
\hline Megabittacus spatiosus n. sp. & Yixian Fm. & J3-K1 & Male & 38 & 41 & 1.07 \\
\hline $\begin{array}{l}\text { Palaobittacus eocenicus } \\
\text { Carpenter, } 1928\end{array}$ & $\begin{array}{l}\text { Green River, } \\
\text { Utah }\end{array}$ & Eocene & Female & 13 & 14 & 1.08 \\
\hline Bittacus egestionis Carpenter, 1955 & $\begin{array}{l}\text { Green River, } \\
\text { Utah }\end{array}$ & Eocene & Female & 7 & 8 & 1.14 \\
\hline Bittacus succinus Carpenter, 1954 & Baltic amber & Late Eocene & Male & 15 & 17 & 1.13 \\
\hline $\begin{array}{l}\text { Hylobittacus minimus (Carpenter, } \\
\text { 1954) Krzemiński, } 2007\end{array}$ & Baltic amber & Late Eocene & Male & 12.1 & $13(11.5-13)$ & 1.07 \\
\hline $\begin{array}{l}\text { Hylobittacus antiquus (Pictet, 1854) } \\
\text { Krzemiński, } 2007\end{array}$ & Baltic amber & Late Eocene & Female & 17.1 & 19 & 1.11 \\
\hline \multicolumn{2}{|l|}{ Bittacus lii Zhou, 2003} & Extant & Male & 20 & 25.4 & 1.27 \\
\hline \multicolumn{2}{|l|}{ Bittacus obscures Huang, 2005} & Extant & Male & $13-13.5$ & $18-19$ & 1.39 \\
\hline Bittacus flavidus Huang, 2005 & & Extant & Male & $17-17.5$ & $23.5-24$ & 1.37 \\
\hline Bicaubittacus longiprocessus Tan, 2009 & & Extant & Male & 20 & 20 & 1 \\
\hline Bittacus trapezoideus Huang, 2005 & & Extant & Male & 13 & 17 & 1.31 \\
\hline Bittacus choui Hua \&Tan, 2007 & & Extant & Male & 11 & 16 & 1.45 \\
\hline Bittacus maculosus Byers, 1965 & & Extant & Female & 24 & 23 & 0.96 \\
\hline Kalobittacus hubbelli Byers, 1965 & & Extant & $\mathrm{F} / \mathrm{M}$ & 18 & 18 & 1 \\
\hline Terrobittacus implicates Tan \& Hua, 2009 & & Extant & Male & 11 & $15.3-15.5$ & 1.4 \\
\hline Terrobittacus longisetus Tan \& Hua, 2009 & & Extant & Male & $13.8-14.6$ & $20.3-20.7$ & 1.44 \\
\hline & & & Female & $13.7-15.8$ & $20.2-21.4$ & 1.41 \\
\hline Terrobittacus xiphicus Tan \& Hua, 2009 & & Extant & Male & 12 & 15 & 1.25 \\
\hline Issikiella byersi Penny, 1982 & & Extant & Male & $13.2-15$ & $15.4-16.8$ & 1.14 \\
\hline & & & Female & 12.5 & $15-15.5$ & 1.22 \\
\hline Nannobittacus souzalopesi Penny, 1982 & & Extant & Male & 15 & 16.5 & 1.1 \\
\hline & & & Female & 14 & 17 & 1.21 \\
\hline Nannobittacus tjederi Byers, 1965 & & Extant & Male & 19 & 20.6 & 1.08 \\
\hline Harpobittacus tillyardi Lambkin, 1994 & & Extant & Male & 27.8 est. & $25.3(21.2-26.4)$ & 0.91 est. \\
\hline Symbittacus scitulus Byers, 1986 & & Extant & Female & 13 & 14.1 & 1.08 \\
\hline Orobittacus obscures Villegas \& Byers, 1 & 1981 & Extant & Male & 15.7 & 16.9 & 1.08 \\
\hline & & & Female & 15.0 & 16.8 & 1.12 \\
\hline Pazius gracilis Byers, 1957 & & Extant & Male & 23 & 17 & 0.74 \\
\hline Pazius obtusus Byers, 1957 & & Extant & Male & 23 & 18 & 0.78 \\
\hline
\end{tabular}

Ren, 2007 in the wing venation and size. But the new genus can be distinguished from Antiquanabittacus by these characters: $\mathrm{MP} 3+\mathrm{MP} 4+\mathrm{CuA} 1+2$ not short; no crossvein present between $\mathrm{AA} 3+4$ and $\mathrm{CuP}$; only one crossvein between $\mathrm{MP} 4+\mathrm{CuA} 1+2$ and $\mathrm{CuA} 3+4$. It can also be differentiated from Mongolbittacus by one crossvein between $\mathrm{ScP}$ and RA; RA with one pterostigma crossvein to RP1 and $\mathrm{RP}+\mathrm{MA}$ forking before the fork of MP. This new genus can be easily distinguished from all other fossil genera: hind wing both $\mathrm{RP}+\mathrm{MA}$ and $\mathrm{MP}$ are with three branches; one crossvein between ScP and RA; RA with one pterostigma crossvein to RP1; $\mathrm{RP}+\mathrm{MA}$ forking before the fork of MP; "Kreuz der Bittaciden" aligned, $\mathrm{MP} 3+\mathrm{MP} 4+\mathrm{CuA} 1+2$ forking before posterior part of "Kreuz der Bittaciden" (if existing); one crossvein between $\mathrm{MP} 4+\mathrm{CuA} 1+2$ and $\mathrm{CuA} 3+4$; and $\mathrm{AA} 3+4$ short.

The new genus Exilibittacus n. gen. has both $\mathrm{RP}+\mathrm{MA}$ and MP with four branches in forewings, 


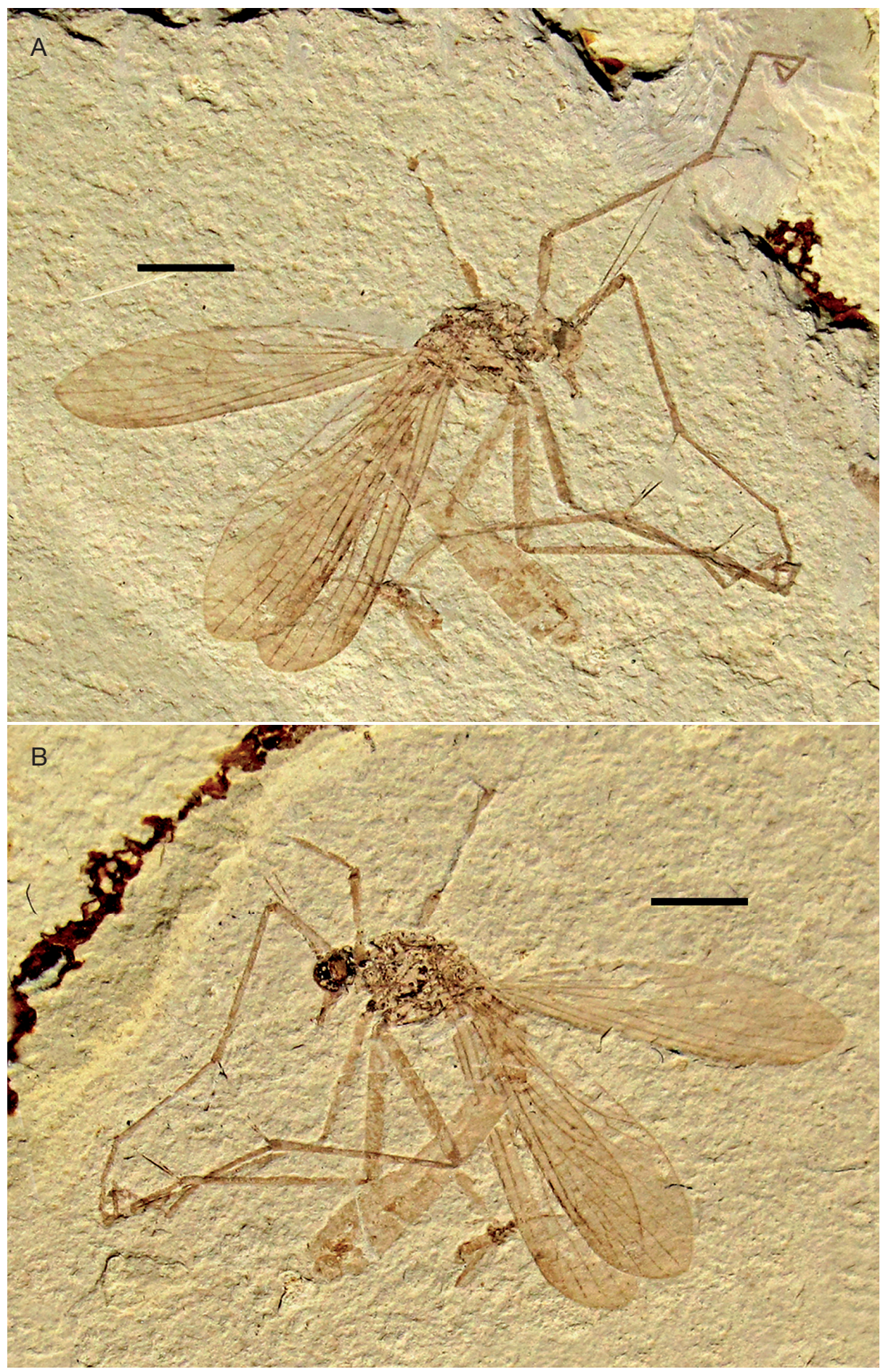

FIG 1. - Exilibittacus lii n. gen., n. sp., holotype: A, part (CNU-M-NN2010001p); B, counterpart (CNU-M-NN2010001c). 
while both with three branches in hind wing; $\mathrm{RP} 1+2$ and MP3 not forking. Up to date, among the described bittacids, only Orobittacus has vein $\mathrm{RP}+\mathrm{MA}$ with three branches (RP1+2 not forking). This is the first time that the character of MP with three branches in hind wings is reported for the Bittacidae.

\section{Exilibittacus lii n. gen., n. sp.} (Figs 1A, B; 2A-F)

HolotyPe. - CNU-M-NN2010001p/c, part and counterpart, lateral view, preserved completely, except for missing right hind wing and partial left middle leg. Deposited at the Key Laboratory of Insect Evolution \& Environmental Changes, the College of Life Sciences, Capital Normal University (CNU), Beijing, China.

Etymology. - The specific name is dedicated to Mr. Junyan Li who kindly donated this important specimen to $\mathrm{CNU}$ from his private collection.

HORIZON AND LOCALITY. - Jiulongshan Formation, Middle Jurassic, Daohugou Village, Shantou Township, Ningcheng County, Inner Mongolia, China.

DiAGNOSIS. - As for the genus by monotypy.

\section{DESCRIPTION}

Female, small sized.

\section{Head}

Vertex of head raised, rostrum long and slender; eyes large; antenna filiform, with short scape, stout pedicel (Figs 1A, B; 2A).

\section{Leg}

Long and slender densely covered by short setae; femur strong, tibia with two terminal spurs; tarsus with five segments, the fifth tarsomere folded against the fourth, with a single, predatory tarsal claw. (Figs 1A, B; 2A, B).

\section{Forewing}

Without thyridium, basal part narrow, gradually broaden to apex; pterostigma slightly dark; $\mathrm{ScP}$ short, ending in the middle of forewing; one crossvein arising at 2/3 of $\mathrm{ScP}$ between $\mathrm{ScP}$ and RA; RA through pterostigma, slightly bent distally, not branched; both $\mathrm{RP}+\mathrm{MA}$ and $\mathrm{MP}$ four branches; $\mathrm{RP}+\mathrm{MA}$ forking before the fork of MP, almost at $1 / 3$ of wing length; $M P 1+2$ forking after RP3+4+MA; RA with two crossveins to RP1+2 and RP1 (one crossvein is pterostigma crossvein); one crossvein between MP1 and MP2; one crossvein between MP2 and MP3; no crossvein present between $\mathrm{AA} 3+4$ and $\mathrm{CuP}$; $\mathrm{AA} 3+4$ short; AP1+2 absent. Right forewing one crossvein between RP2 and RP3+4; one crossvein between RP3+4 and MA; two crossveins between MA and MP1, but these four crossveins absent in left forewing. Left forewing part of "Kreuz der Bittaciden" (mp1+2-mp3 crossvein) preserved. (Figs 1A, B; 2A, C, D).

\section{Hind wing}

Slightly narrower than forewing, apical margin slightly sharp-pointed; one crossvein arising before the end of ScP between ScP and RA; both $\mathrm{RP}+\mathrm{MA}$ and MP with three branches; MP1+2 forking after RP3+4+MA; RA with two crossveins to RP1 (one crossvein is pterostigma crossvein); one crossvein between RP1+2 and RP3+4; one crossvein between RP3+4 and MA; one crossvein between MA and MP1; one crossvein between MP1 and MP2; one crossvein between MP2 and $\mathrm{MP} 3$; one crossvein between $\mathrm{CuA}$ and $\mathrm{CuP}$; $\mathrm{AA} 3+4$ very short, reaching posterior wing margin after the origin of RP; AP1+2 absent. (Figs 1A, B; 2A, E).

\section{Abdomen}

Eight segments visible, T9 fused with T8; terminal abdominal segments well preserved; subgenitalis (bearing a conspicuous patch of large setae), tergum octavum, supra-anale, cercus and subanale visible. (Figs 1A, B; 2A, F).

\section{Measurement}

Body $12 \mathrm{~mm}$ long; forewing $7.5 \mathrm{~mm}$ long, $2.2 \mathrm{~mm}$ wide; hind wing $7.0 \mathrm{~mm}$ long, $1.7 \mathrm{~mm}$ wide.

\section{Genus Megabittacus Ren, 1997}

TYPE SPECIES. - Megabittacus colosseus Ren, 1997. 

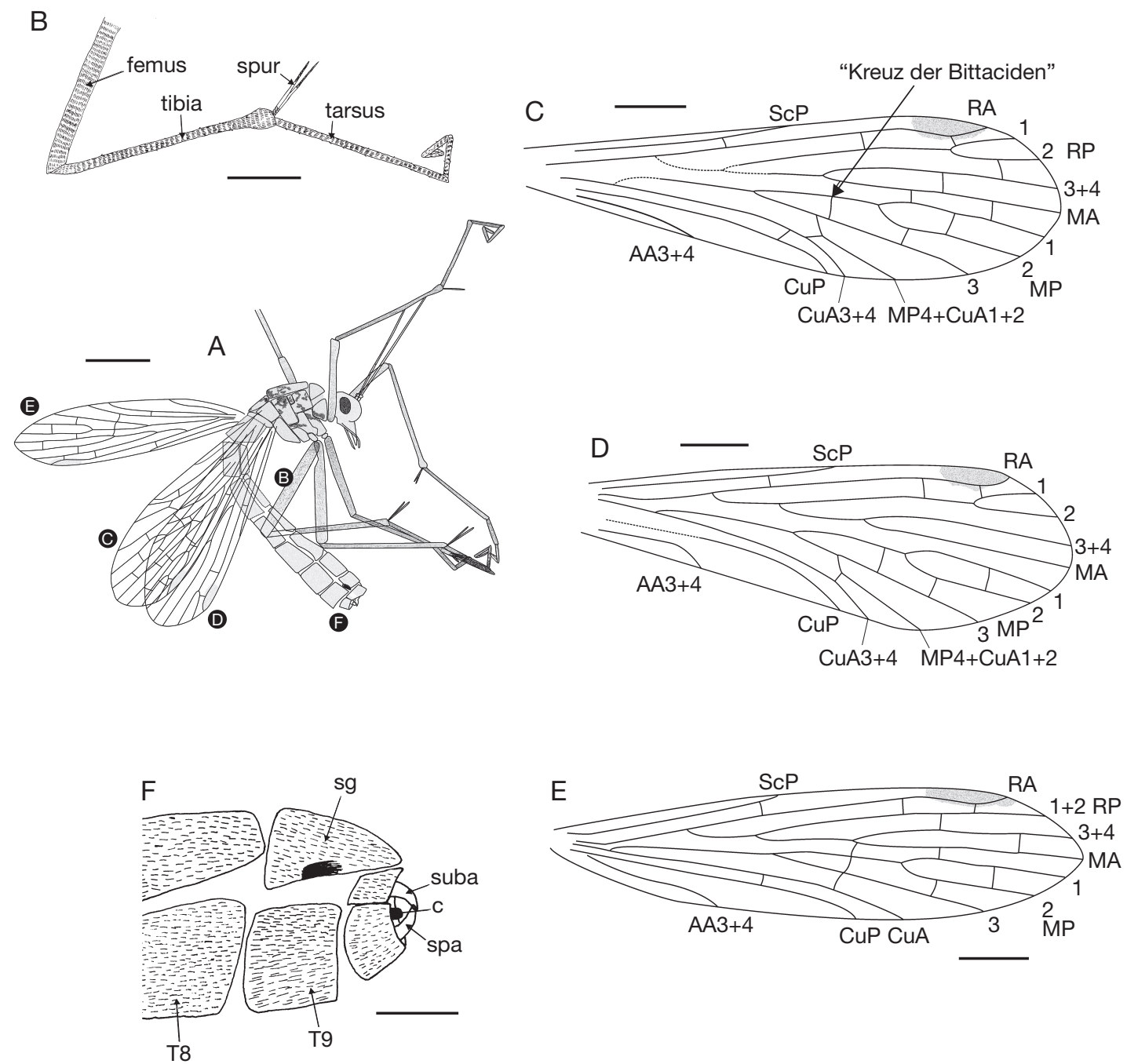

FIG 2. - Exilibittacus lii n. gen., n. sp., line drawings of holotype: A, body with wings; B, left hind leg; C, right forewing; D, left forewing; E, left hind wing; F, genitalia in ventral view. Abbreviations: sg, subgenitalis; suba, subanale; c, cercus; spa, supra-anale; T8, tergum octavum; T9, tergum nonum. Other abbreviations: see Material and methods. Scale bars: A, 2 mm; B-E, 1 mm; F, 0.5 mm.

INCLUDED SPECIES. - M. colosseus, M. beipiaoensis Ren, 1997 and M. spatiosus n. sp.

REVISED DIAGNOSIS. - Three or four crossveins between ScP and RA; RP and MP very long; RP1+2 and RP3+4 notably curved, distance between $\mathrm{RP} 1+2$ and $\mathrm{RP} 3+4$ very short and with one crossvein; "Kreuz der Bittaciden" aligned, $\mathrm{MP} 3+\mathrm{MP} 4+\mathrm{CuA} 1+2$ forking at the same point; $\mathrm{AA} 3+4$ long, extending to posterior wing margin before the level of $\mathrm{RP}+\mathrm{MA}$ forking.
Based on the above discussion, a key to identify species of the genus of Megabittacus is given page 795 .

\section{REMARKS}

Megabittacus Ren, 1997 was erected based on two species (one with nearly complete wing and body; the other with nearly complete wing but body not perserved). Here, we assign a new species, Megabittacus spatiosus 


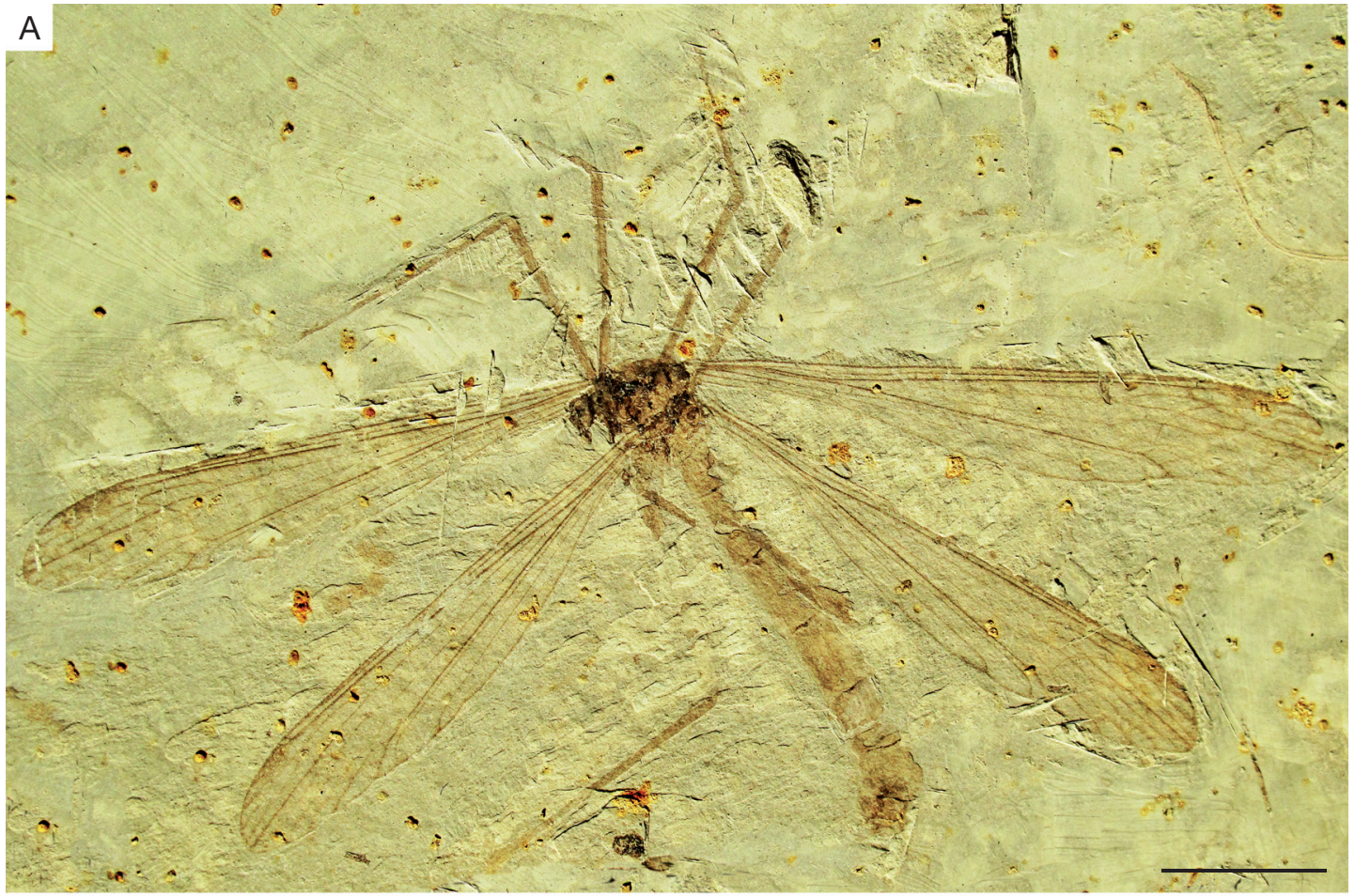

B

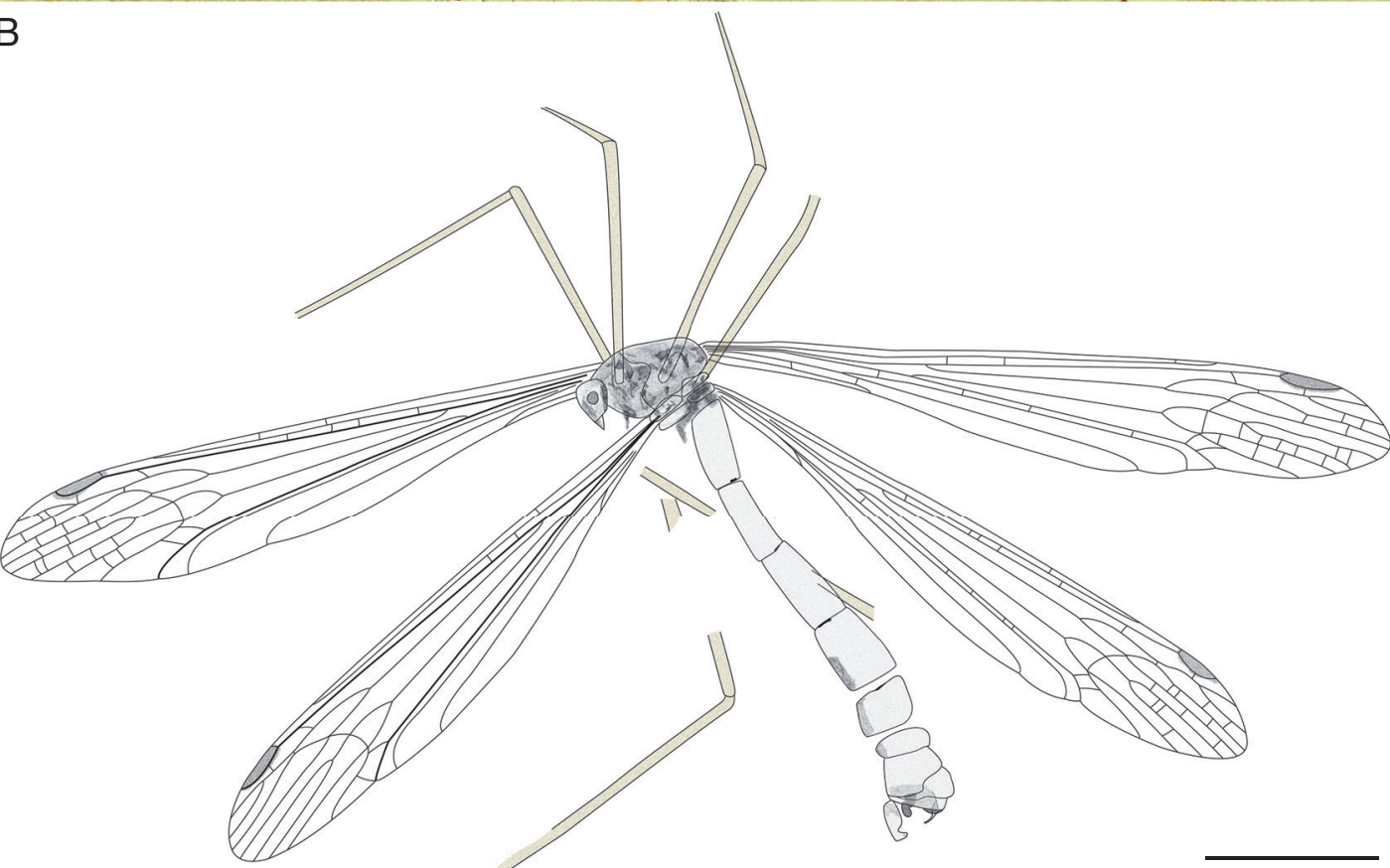

FIG 3. - Megabittacus spatiosus n. sp., photograph and line drawing of holotype: A, holotype (CNU-M-NN2010003); B, line drawing of holotype, body with wings. Scale bars: $10 \mathrm{~mm}$. 

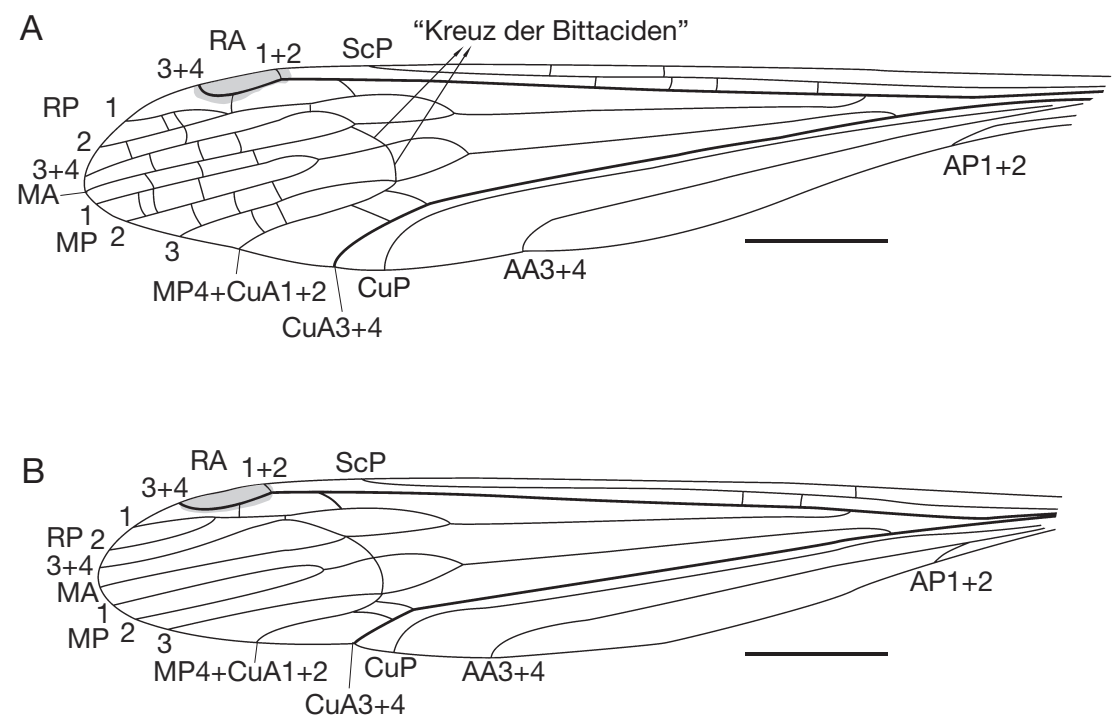

C

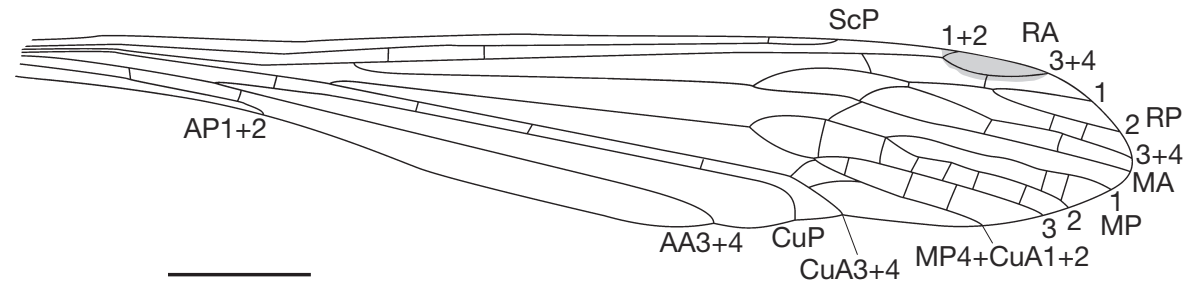

D

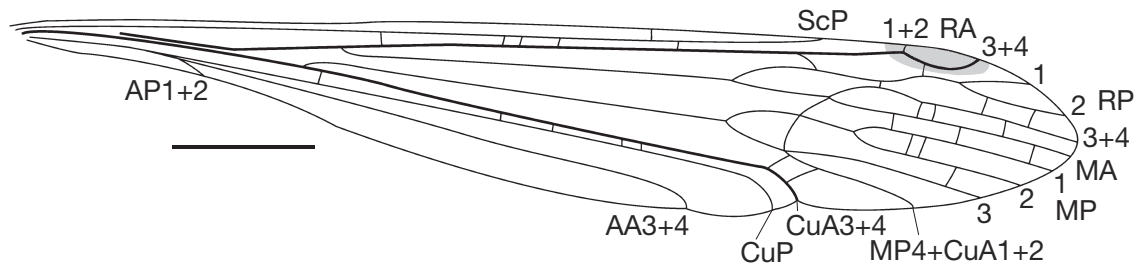

FIG 4. - Megabittacus spatiosus n. sp., line drawings of holotype: A, right forewing; B, right hind wing; C, left forewing; D, left hind wing. Abbreviations: see Material and methods. Scale bar: $5 \mathrm{~mm}$.

n. sp., to this genus based on the following characters: body and wings quite large, wings narrow and long, more than $35 \mathrm{~mm}$ long; three or four crossveins between ScP and RA; RP and MP very long; RP1+2 and $\mathrm{RP} 3+4$ notably curved, distance between $\mathrm{RP} 1+2$ and $\mathrm{RP} 3+4$ very short and with one crossvein. This new species can be differentiated from $M$. colosseus and $M$. beipiaoensis by having an oblique crossvein from RA to $\mathrm{RP} 1+2$ before pterostigma and two crossveins between $\mathrm{MP} 4+\mathrm{CuA} 1+2$ and $\mathrm{CuA} 3+4$ (Fig. 5A, B). Based on this new species, we revised the generic diagnosis of Megabittacus Ren, 1997 as follows (see key). 

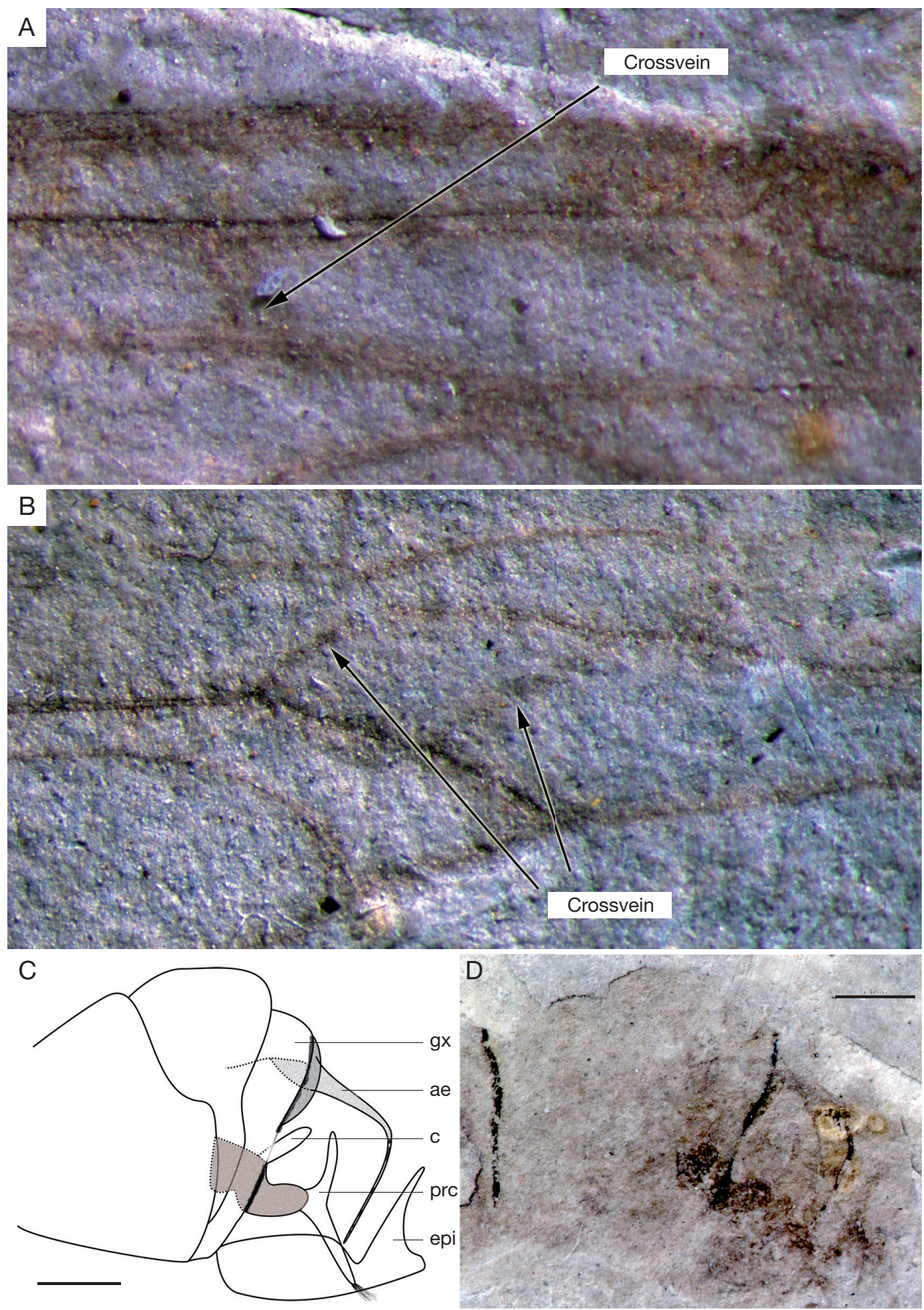

FIG 5. - Megabittacus spatiosus n. sp., photographs and line drawing of holotype: A, photograph of one inclined crossvein before pterostigma; B, photograph of two crossveins between M4 and CuA; C, line drawing of genitalia in ventral view; $\mathbf{D}$, photograph of genitalia in ventral view. Abbreviations: gx, gonocoxite; ae, aedeagus; c, cercus; prc, proctiger; epi, epiandrium. Scale bars: C, D, 1 mm. 


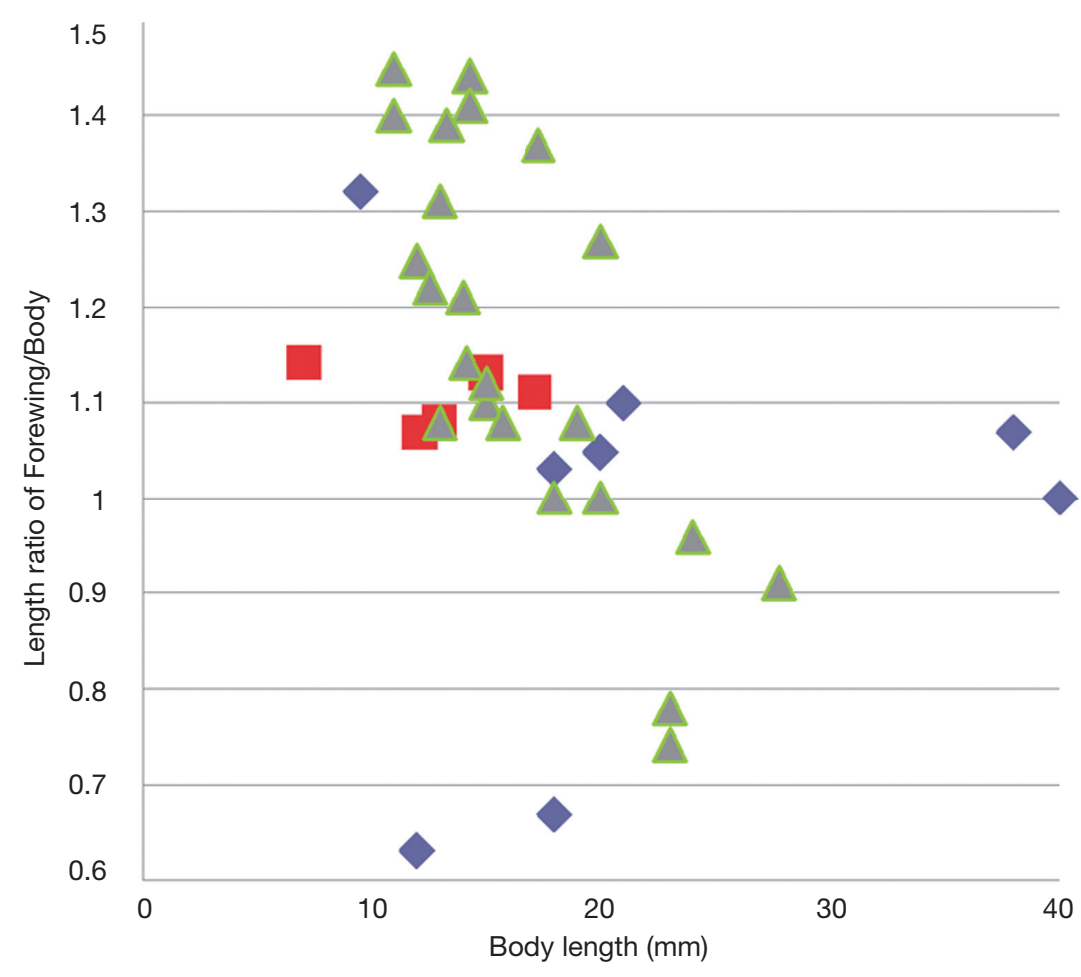

Middle Jurassic to Early Cretaceous

Extant

Eocene

FIG 6. - Length ratios of forewing/body versus body lengths for fossil and extant hangingflies. All data are in $\mathrm{mm}$. Three sets of data are indicated by legends in the Figure.

KEY TO THE KNOWN SPECIES OF MEGABITTACUS REN, 1997

1. $R P+M A$ forking before the level of the fork of MP M. beipiaoensis Ren, 1997

- RP+MA forking slightly after or at the same level of the fork of MP 2

2. One crossvein between $\mathrm{MP} 4+\mathrm{CuA} 1+2$ and $\mathrm{CuA} 3+4$ M. colosseus Ren, 1997

- Two crossveins between MP4+CuA1+2 and $\mathrm{CuA} 3+4$ M. spatiosus $\mathrm{n}$. sp.

Megabittacus spatiosus n. sp. (Figs 3A, B; 4A-D; 5A-D)

HolOTYPE. - CNU-MEC-NN2010003, lateral view, preserved completely. Deposited at the Key Lab of Insect Evolution \& Environmental Changes, the College of Life Sciences, Capital Normal University (CNU), Beijing, China.

Eтyмоlogy. - The Latin word of "spatiosus" means long, indicating elongated body and wing.
LOCALITY AND HORIZON. - Dawangzhangzi in Lingyuan, western Liaoning, China; Yixian Formation, Late Jurassic to Early Cretaceous.

DiagNOSIs. - One oblique crossvein from RA to RP1+2 before pterostigma; two crossveins between $\mathrm{MP} 4+\mathrm{CuA} 1+2$ and $\mathrm{CuA} 3+4$.

DESCRIPTION

Male, large sized (Fig. 3A, B). 


\section{Head}

Rostrum short; eyes large; antennae not preserved.

\section{Leg}

Long and slender, preserved partially.

\section{Wings}

Narrow basally, no thyridium, broadening from base towards rounded apex, with broadly convex posterior margin, pterostigma slightly dark. The wings much narrower and longer at the base than those of previously known bittacids, apices rounded; ScP very long, ending not far from the pterostigma, well beyond the fork of RP+MA; RA running through pterostigma, with a short single branch and RA3+4 distally scoop-shaped; $\mathrm{RP}$ arising at a distance of about one quarter length of the wing from the base, $\mathrm{RP}+\mathrm{MA}$ dividing late into four branches. RP1+2 and RP $3+4$ notably curved, the distance between the RP1+2 and RP3+4 very short and one short crossvein connecting them, MP with four branches, $\mathrm{RP} 3+4+\mathrm{MA}$ forking before $\mathrm{MP} 1+2$, slightly after the fork of $\mathrm{MP} 3+\mathrm{MP} 4+\mathrm{CuA} 1+2$; vein $\mathrm{AA} 3+4$ long, extending before the forks of $\mathrm{RP}+\mathrm{MA}$ and $\mathrm{MP}, \mathrm{AP} 1+2$ short; in hind wing, $\mathrm{AP} 1+2$ coalesced with $\mathrm{AA} 3+4$ for a long distance.

Right forewing ScP with two crossveins reaching the wing anterior margin; an oblique basad crossvein from RA to RP1+2 ending before pterostigma; four crossveins between ScP and RA; two crossveins between RP1 and RP2, two crossveins between RP2 and $\mathrm{RP} 3+4$, three crossveins between $\mathrm{RP} 3+4$ and MA, three crossveins between MA and MP1, three crossveins between MP1 and MP2, three crossveins between MP2 and MP3, two crossveins between MP3 and MP4+CuA1+2 (Fig. 4A).

Left forewing $\mathrm{ScP}$ with one crossvein reaching anterior margin; an oblique apicad crossvein from RA to RP1+2 before pterostigma; two crossveins between ScP and RA; two crossveins between RP2 and $\mathrm{RP} 3+4$, two crossveins $\mathrm{RP} 3+4$ and $\mathrm{MA}$, two crossveins between MP1 and MP2, five crossveins between MP2 and MP3, three crossveins between $\mathrm{MP} 3$ and $\mathrm{MP} 4+\mathrm{CuA} 1+2$, four crossveins between $\mathrm{CuA} 3+4$ and $\mathrm{CuP}$, two crossveins between $\mathrm{AA} 3+4$ and $\mathrm{AP} 1+2$ (Fig. 4C).

Right hind wing $\mathrm{ScP}$ with one crossvein to anterior margin; an oblique basad crossvein from RA to
RP1+2 ending before pterostigma; two crossveins between ScP and RA; no crossveins preserved in RP, MA and MP (Fig. 4B).

Left hind wing $\mathrm{ScP}$ with one crossvein reaching anterior margin; five crossveins between $\mathrm{ScP}$ and $\mathrm{RA}$; an oblique apicad crossvein from RA to RP1+2 before pterostigma; two crossveins between RP2 and $\mathrm{RP} 3+4$, three crossveins between $\mathrm{RP} 3+4$ and MA, three crossveins between MA and MP1, two crossveins between MP1 and MP2, one crossvein between MP2 and MP3, five crossveins between $\mathrm{CuA} 3+4$ and $\mathrm{CuP}$ (Fig. 4D).

\section{Abdomen}

Ten segments visible. Genital segment visible, epiandrium long and prong-like, tapering apically with apex curved mesad; upper and low branches of proctiger preserved, upper branch of proctiger with quite long setae; aedeagus of moderate length, recurved (not coiled), with a terminal filamentous extension. (Fig. 5C, D).

\section{Measurement}

The entire body nearly $38.0 \mathrm{~mm}$ long; forewing $41.0 \mathrm{~mm}$ long, $11.5 \mathrm{~mm}$ wide; hind wing $37.2 \mathrm{~mm}$ long, $11.3 \mathrm{~mm}$ wide.

\section{DISCUSSION}

As mentioned earlier, Exilibittacus lii n. gen., n. sp., has interesting and special venation characters. $\mathrm{RP}+\mathrm{MA}$ and $\mathrm{MP}$ of its left hind wing have only three branches and $\mathrm{RP} 1+2$ and $\mathrm{MP} 3+\mathrm{MP} 4+\mathrm{CuA} 1+2$ not forking, even though $\mathrm{RP}+\mathrm{MA}$ and $\mathrm{MP}$ of its left and right forewings have typical four branches, same as those of most hangingflies. This is the first time that the character of MP with three branches is recorded for the Bittacidae. Intra-species venation variation for radial sector has been reported by Carpenter for Panorpodes brevicauda (Hagen): "The additional specimens of brevicauda now at hand show that this is not consistently so: the radial sector has six branches in one specimen, five in another, and four in the third; the media has four branches in all specimens" (Carpenter 1954). Since we have collected only a single specimen of E. lii n. gen., n. sp., so far, we 
don't have comparative information to establish that three branches of $\mathrm{RP}+\mathrm{MA}$ and $\mathrm{MP}$ are indeed stable characters. Therefore, other venation characters were also used to distinguish this new genus from all other known genera. They are: one crossvein between ScP and RA; RA with one pterostigma crossvein to RP1; $\mathrm{RP}+\mathrm{MA}$ forking before the fork of MP; "Kreuz der Bittaciden" aligned, $\mathrm{MP} 3+\mathrm{MP} 4+\mathrm{CuA} 1+2$ forking before posterior part of "Kreuz der Bittaciden" (if existing); one crossvein between $\mathrm{MP} 4+\mathrm{CuA} 1+2$ and $\mathrm{CuA} 3+4$; and $\mathrm{AA} 3+4$ short.

When compared with extant and fossil hangingflies, E. lii n. gen., n. sp. (with a body length of $12.0 \mathrm{~mm}$ and forewing length of $7.5 \mathrm{~mm}$ ) seems to be at the low end of the size range; while $M$. spatiosus n. sp. (with a body length of $38.0 \mathrm{~mm}$ and forewing length of $41.0 \mathrm{~mm}$ ), at the high end of the range. As stated before, hangingflies are predacious insects. For hangingflies, larger body size may give them better advantage in catching larger preys, which in turn increasing their opportunity to mate with females and passing on their genes. On the other hand, larger insects are easier targets to be spotted by predators feeding on insects.

We conducted a literature search for described fossil hangingflies which have preserved body and forewing and their respective length data; and surveyed representative extant hangingflies. Their body length, forewing length, hind wing length, length ratio of forewing/body and other pertinent information are summarized in Table 2. We have eight fossils from the Middle Jurassic to the Early Cretaceous of northeastern China, two fossils from the Eocene of Green River, USA, three Baltic amber fossils from the Late Eocene, and twenty-three representative extant species (in ten out of sixteen extant genera). We plotted length ratios of forewing/body versus body lengths in Figure 6 .

From Table 2 and Figure 6, we can draw the following observations and conclusions:

1) Eight fossils from the Middle Jurassic to the Early Cretaceous, all from northeastern China, have a very wide range of body lengths from 9.5 to $40.0 \mathrm{~mm}$ and a very broad range of length ratios of forewing/body from 0.63 to 1.32 . Findings of these wide varieties of hangingfly fossils in northeastern China suggest a high level of diversity for these hangingflies;

2) Five specimens from the Eocene have body lengths from $7.0 \mathrm{~mm}$ to $17.1 \mathrm{~mm}$ and a very narrow range of length ratio of forewing/body from 1.07 to 1.14. It is probably due to low sample numbers;

3) Twenty three representative extant specimens have a body length range from $11.0 \mathrm{~mm}$ to $27.8 \mathrm{~mm}$. This range, which is narrower than that of the Middle Jurassic to the Early Cretaceous, suggests that very large or very small body sizes had less advantages in the long process of evolution for hangingflies. On the ratio, the range is very broad from 0.74 to 1.45 , the same as that of the Middle Jurassic to the Early Cretaceous; and 4) For extant species (23 specimens), it seems there is a general trend that larger body-sized species have lower ratio of forewing/body with a correlation coefficient of -0.754 . This correlation is not significant for the other two sets of data points as evidenced by very low correlation coefficients, 0.102 (8 specimens) and -0.232 ( 5 specimens) respectively.

Exilibittacus lii n. gen., n. sp. has the lowest ratio of 0.63 , which, in conjunction with its $12.0 \mathrm{~mm}$ body length, distinguishes this species from all other species. This further provides support for setting up a new genus of Exilibittacus n. gen.

In taxonomy study of hangingflies, especially fossil specimens, length of body and wings and length ratio of wing/body would be important characters to supplement other morphological characters, eg. venation, body and antenna, commonly used. However, these two characters should be used as part of a broad spectrum of other characters with cautious and careful consideration. For example, Table 2 shows that for the same genus, e.g., Bittacus, the body lengths are from $7.0 \mathrm{~mm}$ to $24.0 \mathrm{~mm}$, and ratios range from 1.08 to 1.45 for 2 fossil and 6 extant species.

\section{Acknowledgements}

We appreciate help and assistance provided to YXG by Cui Ying, Yang Qiang, Li Shu, and Guo Yinxia in the CNU laboratory. This research is supported by the National Basic Research Program of China (973 Program) (2012CB821906), the National Natural Science Foundation of China (nos 31071964, 31172143, 31230065 and 41272006) and China Geological Survey (1212011120116). At last, we would like to thank Dany Azar, Julian Fernando Petrulevičius and Annemarie Ohler for their reviews, and Olivier Béthoux for the translation of the abstract. 


\section{REFERENCES}

Byers G. W. 1957. - The Neotropical genus Pazius (Mecoptera: Bittacidae). Occasional Papers of the Museum of Zoology 528: 1-7.

BYERS G. W. 1965. - New and uncommon Neotropical Mecoptera. Journal of the Kansas Entomological Society 38(2): 135-144.

Byers G. W. 1979. - Hylobittacus, a new genus of North American Bittacidae (Mecoptera). Journal of the Kansas Entomological Society 52 (2): 402-404.

BYERS G. W. 1986. - A New Australian genus of Bittacidae (Mecotpera). Memoirs the Queensland Museum 22 (2): 165-168.

Carpenter F. M. 1928. - A Scorpion-Fly from the Green River Eocene. Annals of the Carnegie Museum 18: 241-248.

CARPENTER F. M. 1954. - The Baltic amber Mecoptera. Psyche 61: 31-40.

CARPENTER F. M. 1955. - An Eocene Bittacus (Mecoptera). Psyche 62: 39-41.

Chen P. J., Wang Q. F., Zhang H. C., CaO M. Z., LI W. B., WU S. Q., SHEN Y. B. 2004. - Discussion on the stratotype of Jianshangou of Yixian Formation. Science in China Series D34: 883-895 (in Chinese, English abstract).

CHEN W., Ji Q., LiU D. Y., ZHANG Y., SONG, B. \& LiU X. Y. 2004. - Isotope geochronology of the fossilbearing beds in the Daohugou area, Ningcheng, Inner Mongolia. Geological Bulletin of China 23 (12): 1165-1169.

GAO K. Q. \& REN D. 2006. - Radiometric dating of ignimbrite from Inner Mongolia provides no indication of a Post Middle Jurassic Age for the Daohugou Beds. Acta Geologica sinica 80: 42-45.

HaNLIRSCH A. 1906-1908. - Die fossilen Insecten und die Phylogenie der rezenten Formen. Wilhelm von Engelmann, Leipzig, $1430 \mathrm{p}$.

Hua B. Z. \& TAN J. L. 2007. - A New Species of Bittacus Latreille(Mecoptera, Bittacidae) from Daba Monuntain in China. Acta Zootaxonomica Sinica 32 (2): 455-458.

Huang D. Y., Nel A., Shen Y. B., Selden P. A. \& Lin Q. B. 2006. - Discussions on the age of the Daohugou fauna evidencefrom invertebrates. Progress in Natural Science 16: 308-312.

Ji Q., LuO Z. X., Yuan C. X. \& TABRum A. R. 2006. A swimming mammaliaform from the Middle Jurassic and ecomorphological diversification of early mammals. Science 311: 1123-1127.

KUKALOVÁ-PECK J. 1983. - Origin of the insect wing and wing articulation from the arthropodan leg. $\mathrm{Ca}$ nadian Journal of Zoology 61: 1618-1669.

KUKALOVÁ-PECK J. 1991. - Fossil history and the evolution of hexapod structures. The Insects of Australia 141-179.
KRZEMIŃSKI W. 2007. — A revision of Eocene Bittacidae (Mecotera) from Baltic amber, with the description of a new species. African Invertebrates 48 (1): 153-162.

LAMBKIN K. J. 1994. — Revision of the Australian scorpion-fly genus Harpobittacus (Mecoptera: Bittacidae). Invertebrate Taxonomy 8: 767-808.

LatreIlle P. 1805. - Histoire naturelle, générale et particulaire, des Crustacs et des Insectes. Paris, $1805 \mathrm{p}$.

Li P. X., Cheng Z. W. \& PAng Q. Q. 2001. - The horizon and age of the Confuciusornis in Beipiao, western Liaoning. Acta Geologica Sinica 75 (1): 1-13 (in Chinese, English abstract).

Li Y. L., ReN D. \& SHIH C. K. 2008. — Two Middle Jurassic hanging-flies (Insecta: Mecoptera: Bittacidae) from Northeast China. Zootaxa 1929: 38-46.

Li Y. L. \& ReN D. 2009. — Middle Jurassic Bittacidae (Insecta: Mecoptera) from Daohugou, Inner Mongolia, China. Acta Zootaxonomica Sinica 3: 560-567.

LiU Y. Q., LiU Y. X., LI P. X., Zhang H., ZhanG L. J., Li Y. \& XiA H. D. 2004. — Daohugou biota-bearing lithostratigraphic succession on the southeastern margin of the Ningcheng basin, Inner Mongolia, and its geochronology. Geological Bulletin of China 23 (12): 1180-1185.

MARTYNOV A. V. 1951. - [Two new species of Lower Liassic Insects from Kirghiz]. Bulletin of the Academy of Science, URSS 68 (5): 1009-1011 (in Russian).

NovoKsHONOV V. G. 1993. - Mückenhafte (Mecoptera Bittacidae) aus dem Jura, Kreide und Paläogen von Eurasien und ihre phylogenetischen Beziehungen. Russian Entomological Journal 2 (3-4): 75-86.

NovOKSHONOV V. G. 1997. — Early Evolution of Scorpionflies (Insecta: Panorpida). Nauka Press; Moscow, Russia, 140 p. (in Russian).

NovoKSHONOV V. G. 2002. — Order Panorpida Latreille, 1802, in RasNitsyn A. P. \& Quicke D. L. J. (eds) History of Insects. Dordrecht etc.: Kluwer Academic Publishers 194-199 p.

PACKARD A. S. 1886. - A new arrangement of the orders of insects. The American Naturalist 20 (9): 808.

Pang Q. Q., Li P. X., Tian S. G. \& LiU Y. Q. 2002. — Discovery of ostracods in the Dabeigou and Dadianzi Formations at Zhangjiagou, Luanping County, northern Hebei province of China and new progress in the biostratigraphic boundary study. Geological Bulletin of China 21 (6): 329-336 (in Chinese, English abstract).

Penny N. D. \& Arias J. R. 1982. - Notes on Amazonian Bittacidae (Mecoptera) with the descriptions of two new species. Memorias do Instituto Oswaldo Cruz 77 (3): 263-274.

Petrulevičius J. F. \& Jarzembowski E. A. 2004. - The first hangingfly (Insecta: Mecoptera: Bittacus) from the Cretaceous of Europe. Journal of Paleontology 78 (6): 1198-1201.

Petrulevičius J. F., Huang D. Y. \& Ren D. 2007. A new hangingfly (Insecta: Mecoptera: Bittacidae) 
from the Middle Jurassic of Inner Mongolia, China. African Invertebrates 48 (1): 145-152.

REN D. 1993. - First discovery of fossil bittacids from China. Acta Geologica Sinica 67: 376-381.

REN D. 1994. - Discovery of fossil Bittacids in China. Acta Geologica Sinica 7 (2): 219-224.

REN D. 1997. - Studies on Late Jurassic scorpion-flies from Northeast China. Acta Zootaxonomica Sinica 22 (1): 75-85.

Ren D. \& KRZEMIŃSKI W. 2002. — Eoptychopteridae (Diptera) from the Middle Jurassic of China. Annales Zoologici 52 (2): 207-210.

ReN D., Lu L.W., GuO Z. G. \& Ji S. A. 1995. — Faunae and stratigraphy of Jurassic-Cretaceous in Beijing and the adjacent Areas. Seismic Publishing House: 64-73.

Ren D., GaO K. Q., Guo Z. G., Tan J. J. \& Song Z. 2002. - Stratigraphic division of the Jurassic in the Daohugou area Ningcheng, Inner Mongolia. Geological Bulletin of China 21 (8-9): 584-591.

SETTY L. R. 1940. - Biology and morphololgy of some North American Bittacidae (Order Mecoptera). The American Midland Naturalist 23 (2): 257-353.

Shen Y. B., Chen P. J. \& Huang D. Y. 2003. Age of the fossil conchostracans from Daohugou of Ningcheng, Inner Mongolia. Journal of Stratigraphy 27 (4): 311-313.

SuKATCHEVA I. D. 1990. — Scorpionflies. Panorpida, in Rasnitsyn A. P. (ed.), Late Mesozoic Insects of Eastern Transbaikalia [Pozdnemezozoyskie nasekomye Vostochnogo Zabaykalya]. Transactions of the Paleontological Institute of the USSR Academy of Sciences [Trudy Paleontologicheskogo instituta Akademii nauk SSSR] 239: 88-94 (in Russian).

Swisher C. C., Wang Y. Q., Wang X. L., Xu X. \& WANG Y. 1999. - Cretaceous age for the feathered dinosaurs of Liaoning, China. Nature 400: 58-61.

TAN J. L. \& Hua B. Z. 2009. - Terrobittacus, a new genus of the Chinese Bittacidae (Mecoptera) with descriptions of two new species. Journal of Natural History 43(47-48): 2937-2954.

TAN J. L. \& HuA B. Z. 2009. - Bicaubittacus, a new genus of the Oriental Bittacidae (Mecoptera) with descriptions of two new species. Zootaxa 2221: 27-40.

Tillyard R. J. 1933. - The Panorpoid Complex in the British Rhaeic and Lias. Britain Museum Fossil Insects 3: 1-79.

VILLEGAS B. \& BYERS G. W. 1981. — Orobittacus obscurus, a new genus and species of Bittacidae (Mecoptera)from California. Pan-Pacific Entomologist 57 (3):385-396.

Wang W. L., Zhang L. J., Zheng S. L., Zheng Y. J., ZHANG H., Li Z. T. \& YANG F. L. 2004. - A new study on the stratotype and biostratigraphy of the Yixian stage in YixianeBeipiao region, Liaoningestablishment and study of stratotypes of the Yixian stage. Acta Geologica Sinica 78 (4): 433-447 (in Chinese, English abstract).

WANG W. L., ZHANG L. J., ZHENG S. L., REN D., ZHENG Y. J., Zhang H., LI Z. T. \& YANG F. L. 2005. — The age of the Yixian stage and the boundary of JurassicCretaceouse the establishment and study of stratotypes of the Yixian stages. Geological Review 51 (3): 234-242 (in Chinese, English abstract).

Willmann R. 1977. - Mecopteran aus dem untereozänen Moler des Limfjordes (Dänemark). Neues Jahrbuch für Geologie und Paläontologie, Monatschefte 1977 (12): 735-744.

Willmann R. 1989. - Evolution und Phylogenetisches System der Mecoptera (Insecta: Holometabola). Abhandlungen der Senckenbergischen Naturforschenden Gesellschaft 544: 1-153.

Zheng S. L., Zheng Y. J. \& XING D. H. 2003. - Characteristics, age and climate of Late Jurassic Yixian flora from western Liaoning. Journal of Stratigraphy 27 (3): 233-241 (in Chinese, English abstract).

ZHOU W. B. 2003. - Four new species of Mecoptera from China. Wuyi Science Journal 19: 88-94.

Submitted on 15 May 2011; accepted on 22 September 2011. 